\title{
ANALISIS PSIKOLOGIS NOVEL DAUN YANG JATUH \\ TAK PERNAH MEMBENCI ANGIN \\ KARYA TERE LIYE
}

\author{
Rusda Nita Nelly Manurung \\ Jurusan Pendidikan Bahasa dan Sastra Indonesia \\ PPs Universitas Negeri Medan \\ e-mail:rusdanitanellymanurung@yahoo.co.id
}

\begin{abstract}
Abstrak..Penelitian ini bertujuan untuk mendeskripsikan gambaran psikologis tokohtokoh yang terdapat dalam novel "Daun yang Jatuh Tak Pernah Membenci Angin" Karya Tere Liye. Metode yang digunakan dalam penelitian ini adalah metode deskriptif. Sumber data pada penelitian ini adalah seluruh isi dari novel Daun yang Jatuh Tak Pernah Membenci Angin Karya Tere Liye. Yang terdiri dari 264 halaman terbitan PT. Gramedia Pustaka Utama tahun 2015 cetakan ke-19. Data penelitiannya yaitu gambaran psikologis yang terdapat pada tokoh-tokoh dalam novel tersebut. Instrumen yang digunakan dalam penelitian ini adalah studi dokumentasi.

Setelah data dianalisis diperoleh hasil yang menunjukkan bahwa gambaran psikologis yang terjadi pada tokoh-tokoh yang terdapat dalam novel Daun yang Jatuh Tak Pernah Membenci Angin Karya Tere Liye. Terungkap jelas pada tokoh Tania dalam novel Daun yang Jatuh Tak Pernah Membenci Angin karya Tere Liye adalah seorang gadis cerdas, tangguh, dan dan memiliki prinsip hidup yang kuat, ia memiliki gejala-gejala kejiwaan yaitu kesedihan atau duka cita yang mendalam, kebencian atau perasaan benci, perasaan marah, perasaan bersalah, menghukum dirinya sendiri, dan yang terakhir cinta.

Tokoh Danar dalam novel Daun yang Jatuh Tak Pernah Membenci Angin karya Tere Liye adalah berhati baik, penolong, dan pekerja keras, ia memiliki gejala-gelaja kejiwaan yaitu perasaan marah, merasa bersalah yang mendalam, kesedihan atau duka cita, menghukum diri sendiri dan yang terakhir cinta.
\end{abstract}

Kata Kunci: Analisis Psikologis, Novel Daun yang Jatuh Tak Pernah Membenci Angin

\section{PENDAHULUAN}

Sastra adalah ungkapan pribadi menghaluskan jiwa karena sastra adalah manusia yang berupa pengalaman, hasil ungkapan kejiwaan atau perasaan pemikiran, perasaan, ide, semangat keyakinan dalam suatu bentuk gambaran konkret yang membangkitkan pesona dengan alat bahasa. Sastra bisa seorang pengarang.

Sastra lahir dari pengekspresian endapan pengalaman yang telah lama ada dalam jiwa seseorang dan telah mengalami 
proses pengolahan jiwa melalui proses berimajinasi. Sastra selalu menarik perhatian karena mengungkapkan tentang kehidupan manusia baik secara nyata maupun imajinatif.

Hasil imajinasi tersebut dituang ke dalam bentuk karya sastra yang dihidangkan kepada pembaca untuk dinikmati. Dengan demikian karya sastra bukanlah suatu uraian kosong atau khayalan yang yang menghibur saja, tetapi melalui karya sastra diharapkan pembaca lebih arif dan bijaksana dalam bertindak dan berfikir.

Kemunculan karya sastra di kehidupan masyarakat sangat membutuhkan pemikiran yang tinggi bagi penikmatnya karena karya sastra akan menimbulkan beranekaragam ide-ide penikmatnya dan sangat menuntut penikmat karya sastra tersebut untuk berpikir dan berpikir lagi. Jadi, tidak salah dikatakan bahwa karya sastra adalah cermin kehidupan masyarakat.

Karya sastra menurut ragamnya terbagi menjadi tiga, yaitu prosa, puisi, dan drama. Berkaitan dengan prosa fiksi umumnya dibagi menjadi dua, cerita pendek (cerpen) dan novel, persoalan yang disodorkan oleh pengarang tidak terlepas dari pengalaman kehidupan nyata seharihari. Hanya saja dalam penyampaiannya, pengarang sering mengemasnya dengan gaya yang berbeda-beda dan syarat pesan bagi kehidupan manusia.

Psikologi pada mulanya digunakan para ilmuan untuk memenuhi kebutuhan mereka dalam memahami akal pikiran dan tingkah laku aneka ragam makhluk hidup mulai dari yang primitif dan yang paling modern. Sastra sebagai "gejala kejiwaan" di dalamnya terkandung fenomena-fenomena kejiwaan yang tampak melalui prilakuprilaku tokohnya. Dengan demikian, karya sastra dapat didekati dengan menggunakan pendekatan psikologi.

Sastra menyajikan ungkapan kejiwaan manusia dalam bentuk seni, sedangkan psikologi mempelajari prosesproses kejiwaan manusia. Sastra lahir dari ekspresi pengalaman yang telah mengalami proses konsep kemudian diolah dalam suasana batinnya sendiri, dituangkan ke dalam karya sastra yang terproyeksi lewat ciri-ciri para tokohnya.

Psikologi dan sastra memiliki hubungan yang fungsional, yakni samasama berguna untuk mempelajari keadaan kejiwaan manusia. Hanya perbedaanya, gejala kejiwaan yang ada di dalam karya sastra adalah gejala-gejala kejiwaan dari manusia-manusia imajiner, sedangkan dalam psikologi adalah manusia rill. Namun, keduanya dapat saling melengkapi dan 
mengisi untuk memperoleh pemahaman yang lebih mendalam terhadap kejiwaaan manusia.

Dalam novel Daun yang Jatuh Tak Pernah Membenci Angin karya Tere Liye terdapat prilaku dan gejala kejiwaan yang berbeda dari setiap tokoh, para tokoh mengalami konflik kejiwaan yang bermula dari sikap kejiwaan tertentu kemudian bermuara ke permasalahan kejiwaan lainnya. Novel Daun yang Jatuh Tak Pernah Membenci Angin karya Tere Liye merupakan novel yang digemari pembaca dalam kesusastraan indonesia.

Novel ini mengisahkan kehidupan kakak beradik Tania dan Dede yang harus putus sekolah dan menjadi pengamen karena keterbatasan ekonomi keluarga sepeninggal ayah mereka. Mereka tinggal di rumah kardus dengan ibu mereka yang sakitsakitan. Kehidupan mereka berubah ketika mereka bertemu dengan seorang pria bernama Danar. Danar adalah seorang karyawan yang juga penulis buku anakanak. Danar begitu baik sehingga keluarga ini menganggapnya seperti malaikat. Tania sangat mengagumi Danar karena selain baik, dia juga punya wajah yang menawan.

Kebahagiaan mereka berkurang saat ibu Tania meninggal. Sekarang ia yang harus bertanggung jawab menjaga adiknya. Tania tumbuh menjadi gadis yang cantik dan pintar. Perasaannya terhadap Danar juga semakin jelas. Lambat laun Tania tahu, perasaan itu bernama cinta. Ia berhasil mendapatkan beasiswa ke Singapura. Ketika Tania dan Danar sama-sama tahu perasaan mereka masing-masing, semua sudah terlambat. Biar bagaimanapun Danar telah menikah dengan Ratna. Akhirnya Tania kembali ke Singapura dan memutuskan untuk meninggalkan semua cerita cintanya.

Novel Daun yang Jatuh Tak Pernah Membenci Angin karya Tere Liye ini mampu menggugah hati setiap pembaca. Air mata pembaca akan jatuh ketika membaca dari halaman satu ke halaman berikutnya. Novel ini indah meskipun akhir ceritanya tidak begitu bahagia. Tere Liye salah satu penulis yang telah banyak menelurkan karya-karya terbaik. Selain memiliki tingkat kesusastraan tinggi, ia merupakan sastrawan yang misterius. Berbeda dengan penulis-penulis lain, Tere Liye memang sepertinya tidak ingin dipublikasikan ke umum terkait kehidupan pribadinya. Mungkin cara yang ia pilih untuk mendekatkan diri dengan pembaca setia karya-karyanya adalah dengan cara memberikan karya terbaiknya. Dari karya-karyanya Tere Liye ingin membagi pemahaman bahwa sebetulnya hidup ini tidaklah rumit seperti yang sering 
terpikir oleh kebanyakan orang. Hidup adalah anugrah sang Kuasa dan karena anugrah berarti harus disyukuri.

Sehubungan dengan pemaparan di atas, peneliti merasa tertarik untuk meneliti novel Daun yang Jatuh Tak Pernah Membenci Angin karya Tere Liye melalui pendekatan psikologi sastra. Guna menyelesaikan persoalan yang dihadapi akan digunakan psikologi kepribadian sebagai alat bantunya. Sebagai kajian yang melatarbelakangi adanya keinginan untuk mengetahui gambaran psikologi tokoh dari segi psikologisnya. Berdasarkan uraian di atas, maka penelitian ini mengambil judul Analisis Psikologis Novel Daun yang Jatuh Tak Pernah Membenci AnginKarya Tere Liye.

\section{KAJIAN TEORI}

\section{Hakikat Pendekatan Psikologis Sastra}

Karto (dalam Emzir, 2015:161) psikologi adalah ilmu pengetahuan tentang tingkah laku dan kehidupan psikis (jiwa) manusia.

Wellek (dalam Nyoman, 2015:61) menunjukkan empat model pendekatan psikologis, yang dikaitkan dengan pengarang, proses kreatif, karya sastra dan pembaca.
Sapardi (2009:42), sastra adalah pandangan yang terwujud sebagai dokumen dunia batin masyarakat sebagaimana terwujud dalam batin pengarang dan tokohtokoh ciptaannya.

Hardjanah (1985:66) menyatakan bahwa psikologi sastra merupakan suatu pendekatan yang mempertimbangkan segisegi kejiwaan dan menyangkut batiniah manusia. Lewat tinjauan psikologi akan nampak bahwa fungsi dan peran sastra adalah untuk menghidangkan citra manusia yang seadil-adilnya dan sehidup-hidupnya atau paling sedikit untuk memancarkan bahwa karya sastra pada hakikatnya bertujuan untuk melukiskan kehidupan manusia.

Rokhmansyah (2014: 160) Psikologi sastra secara umum bertujuan untuk memahami aspek-aspek kejiwaan yang terkandung dalam suatu karya sastra.

Berdasarkan teori-teori yang dikemukakan oleh pakar-pakar tersebut dapat disimpulkan bahwa psikologi sastra adalah cabang ilmu sastra yang memandang karya sastra sebagai aktivitas kejiwaan yang menganalisis karya sastra dari sudut psikologi. Psikologi sangat berperan penting dalam menganalisis sebuah karya sastra dengan bekerja dari sudut kejiwaan karya sastra tersebut baik dari unsur pengarang, 
tokoh, maupun pembacanya. Dengan dipusatkan perhatian pada tokoh-tokoh, maka akan dapat dianalisis konflik batin yang terkandung di dalam sastra.

\section{Aspek-aspek pendekatan Psikologis Sastra}

Endraswara (2002:178) aspek-aspek psikologis sastra adalah:

\section{a. Psikologi Pengarang}

Psikologis pengarang terdiri dari empat bagian yaitu:

\section{1) Memori Psikologi Pengarang}

Memori adalah persoalan siapa pun, termasuk pengarang. Pengarang dengan sendirinya akan menggunakan memorinya untuk berkarya. Sayangnya memori tersebut terbatas. Jarang pengarang mengingat seluruh hal. Ingatan merupakan faktor psikis yang sangat penting bagi pengarang. Hanya melalui ingatan karya dapat dibagun secara intensif.

Memori yang menyelimuti pengarang, ada empat faktor psikologi yaitu pikiran, perasaan, intuisi, dan sensasi.

\section{2) Tipologi Psikis Pengarang}

Keadaan psikis pengarang adalah suasana unik. Pengarang hidup dari suasana yang lain dari yang lain. Pada realitas semacam ini, tugas peneliti psikologis sastra hendaknya lebih menukik sampai sampai hal-hal yang bersifat pribadi. Sastrawan juga dapat dibagi ke dalam dua tipe psikologis, yaitu sastrawan yang "kesurupan" (possessed) yang penuh emosi, menulis dengan spontan dan yang meramal masa depan dan sastrawan "pengrajin" (maker) yang penuh keterampilan, terlatih dan bekerja serius dan penuh tanggungjawab.

\section{3) Psikobudaya pengarang}

Psikobudaya adalah kondisi pengarang yang tidak lepas dari aspek budaya. Kejiwaan pengarang dituntun oleh kondisi budayanya. Pengarang yang bebas sama sekali dari faktor budaya, hampir tidak ada. Faktor budaya akan mempengaruhi secara halus dalam jiwa pengarang. Pengarang tidak bisa lepas dari budaya, pribadi, dan moral yang mengitari jiwanya. Oleh sebab itu, kreativitas pengarang sebenarnya merupakan "cetak ulang" dari jiwanya. Pengarang yang hidupnya penuh dengan liku-liku kultural, tentu amat kaya jiwanya.

\section{4) Kepribadian pengarang}

$$
\text { Kepribadian pengarang adalah }
$$
persoalan jiwa pengarang yang asasi. Pribadi pengarang akan memengaruhi ruh karya. Dari suatu penelitian tentang pendapat para ahli psikologi di indonesia mengenai ciri-ciri 
kepribadian kreatif. Munandar (dalam Endraswara, 1997:152) diperoleh urutan ciri-ciri sebagai berikut: (a). Imajinatif, (b) berprakarsa (dapat memulai sesuatu sendiri), (c) Mempunyai minat yang luas, (d) Mandiri (bebas) dalam berfikir, (e) rasa ingin tahu yang kuat, (f) kepetualangan, (g) penuh semangat, energik, (h) percaya diri, (i) bersedia mengambil resiko, (j) berani dalam keyakinan.

\section{b. Psikologi Pembaca}

Resepsi pembaca secara psikologis pasti akan terjadi, dibandingkan resepsi yang lain. Penerimaan nilai sastra biasanya justru berasal dari aspek psikologis dengan modal kejiwaan, karya sastra akan meresap secara halus dalam diri pembaca. Oleh sebab itu, pembaca yang bagus tentu mampu meneladani aspek-aspek penting dalam sastra. Nilai-nilai dalam sastra yang mampu membentuk sikap dan prilaku akan diinternalisasikan dalam diri pembaca. Sastra dalam konteks pembaca akan berpengaruh cepat dan lambat.

\section{c. Psikologi Penokohan}

Tokoh adalah figur yang dikenai. Tokohtokoh yang muncul dibangun untuk melakukan sebuah objek. Tokoh yang termaksud secara psikologis menjadi wakil sastrawan. Sastrawan terkadang menyelinapkan pesan melalui tokoh. Tokoh yang menjadi tumpuan psikologis sastra, berarti perlu diidentifikasi. Bisa saja di dalam karya tersebut tokoh menjadi cermin diri sastrawan dalam analisis, pada umumnya yang menjadi tujuan adalah tokoh utama. Tokoh menjadi cerminan diri pengarang. Tokoh yang digarap kental, dengan perwatakan yang memukau akan menjadi daya tarik khusus.

\section{Pengertian dan Jenis-jenis Tokoh}

\section{a. Pengertian Tokoh}

Sebuah prosa fiksi didukung oleh tokoh atau pemain. Aminudin (2002:274) "Tokoh adalah pelaku yang mengemban pristiwa dalam cerita fiksi sehingga pristiwa itu mampu menjalin suatu cerita". Kemudian Nurgiyantoro (1995:165) “Tokoh adalah salah satu unsur yang penting dalam suatu novel atau cerita rekaan".

Berdasarkan pendapat para ahli di atas dapat disimpulkan bahwa, tokoh cerita adalah individu rekaan yang dibentuk melalui imajinasi pengarang yang mempunyai watak dan prilaku tertentu sebagai pelaku yang mengalami peristiwa dalam cerita.

\section{b. Jenis-jenis Tokoh}

Sifat dan kedudukan tokoh cerita di dalam suatu karya sastra beranekaragam. 
Dilihat dari segi plot ada yang bersifat penting (utama) dan ada pula yang tidak terlalu penting (tambahan). Nurgiyantoro (1995:176) "Tokoh utama adalah tokoh yang digunakan penceritanya dalam sebuah cerita yang bersangkutan". Tokoh ini merupakan tokoh yang paling banyak diceritakan baik sebagai pelaku kejadian maupun yang dikenai tambahan. Tokoh tambahan kejadiannya lebih sedikit dibandingkan tokoh utama. Kejadiannya hanya ada jika berkaitan dengan tokoh utama secara langsung. Tokoh utama dalam sebuah novel, mungkin lebih dari satu orang, atau kadar keutamaannya tidak terlalu sama. Keutamaan mereka ditentukan oleh dominasi, banyaknya penceritaan, dan pengaruhnya terhadap perkembangan plot secara keseluruhan.

Dilihat dari fungsi penampilan tokoh ada yang berkedudukan sebagai protagonis dan antagonis. Tokoh protagonis adalah tokoh yang berperan sebagai penggerak cerita karena perannya, protagonis adalah tokoh yang pertama-tama menghadapi masalah dan terlibat dalam kesukaran-kesukaran. Biasanya kepadanya pembaca berempati. Lawannya adalah antagonis. Antagonis berperan sebagai penghalang dan masalah bagi si protagonis .

\section{Tipologi Manusia}

Spranger (dalam Suryabrata, 2011:87) menjadikan manusia menjadi enam golongan atau enam tipe. Menurut Spranger dengan adanya tipe-tipe manusia ideal tersebut orang dapat menempatkan individuindividu yang menghadapinya paling dekat ke golongan atau tipe yang mana. Tipe-tipe tersebut yaitu:
a) Manusia Teori

Seorang manusia teori adalah seorang yang intelektualitas sejati, manusia ilmu, cita-cita utama adalah mencapai keberadaannya dan hakikat daripada bendabenda. Tujuan yang dikejar oleh manusia teori adalah pengetahuan yang objektif, sedangkan hal lain seperti moral, keindahan dan sebaginya terdesak kebelakang. Manusia seperti ini adalah ahli pikir yang logis dalam kehidupan sehari-hari ia adalah seorang pencinta kebenaran, konsekuen dan nuchter.

Sikapnya terhadap nilai-nilai yang lainnya pun terpengaruh oleh nilai-nilai teori itu:

- Ia asing terhadap utilisme yang menjadi pedoman dalam lapangan ekonomi; kurang mengindahkan kesenangan hidup dan kurang menghargai kekayaan, akan tetapi 
bukan kekayaan akan harta benda, melainkan kekayaan akan pengetahuan yang benar.

- Manusia teori tidak menaruh perhatian kepada masalah-masalah keindahan; sebagai manusia teori ia menghendaki hal-hal yang berlaku umum dan obyektif, sedangkan seniman-seniman justru menghendaki hal-hal yang individual.

- Jika sekiranya manusia teori itu tidak asing terhadap keagamaan, maka ia tidak akan meninjau masalah keagamaan itu secara rasionalisme.

- Perhatiannnya terhadap masyarakat tidak besar. Seringkali bersikap masa bodoh terhadap lingkungan sosialnya, kalau ia bergaul maka akan dipilihnya orang-orang yang sepaham, atau setidaknya orangorang dari golongan cendikiawan, sehingga berguna bagi kemajuan studinya.

- Sikapnya terhadap politik pun tidak berbeda dengan sikapnya terhadap nilai-nilai yang lain, dia tidak ingin berkuasa, tidak giat, dia hanya mengkritik dan melakukan polemik secara teoritis.

b) Manusia Ekonomi

Orang-orang yang termasuk golongan manusia ekonomi ini selalu kaya dengan gagasan-gagasan yang praktis, kurang memperhatikan bentuk tindakan yang dilakukannya, sebab perhatiannya terutama tertuju pada hasil daripada tindakan. Baginya yang nomor satu adalah keindahan. Menilai segala sesuatu dari segi kegunaan dan ekonomisnya, hidupnya dan kepentingannya sendirilah yang lebih penting, dan orang lain yang menarik perhatiannnya selama mereka masih berguna baginya; Penilaian yang dikemukakannya terhadap orang lain, yang dikenakannya terhadap manusia, terutama didasarkan kepada kemampuan kerja dan prestasinya.

Sikap jiwanya yang praktis itu memungkinkan dia dapat mencapai banyak hal di dalam hidupnya; dia mengejar kekayaan dan dengan kekayaannya itu dia akan mencapai yang diinginkannya.

c) Manusia Estetis

Manusia estetis adalah menghayati kehidupan seakan-akan tidak sebagai pemain, tetapi sebagai penonton; dia selalu seorang impresionis, yang menghayati kehidupan secara pasif; disamping itu dapat 
juga dia sebagai seorang ekspresionis, yang mewarnai segala kesan yang diterimanya dengan pandangan jiwa subjektifnya.

Juga manusia estetis itu berkecenderungan ke arah indivisualisme; hubungan dengan orang-orang lain kurang kekal. Apabila dia tidak asing dari keagamaannya itu mungkin akan memuncak pada pendewaan keselarasan dalam alam. Baginya yang nomor satu adalah keindahan.

\section{d) Manusia Agama}

Bagi seseorang yang termasuk kedalam golongan tipe ini segala sesuatu itu diukur dari segi artinya bagi kehidupan rohanian kepribadian, yang ingin mencapai keselarasan antara pengalaman batin dengan arti daripada hidup ini.

e) Manusia Sosial

Sifat utama daripada manusia golongan tipe ini adalah besar kebutuhannya akan adanya resonansi dari sesama manusia; butuh hidup diantara manusia-manusia lain dan ingin mengabdi kepada kepentingan umum. Nilai yang dipandangnya sebagai nilai yang paling tinggi adalah "cinta terhadap sesama manusia", baik yang tertuju kepada individu maupun kepada kelompok manusia.

\section{f) Manusia Kuasa}

Manusia berkuasa bertujuan untuk mengejar kesenangan dan kesadaran akan kekuasaannya sendiri; dorongan pokoknya adalah ingin berkuasa; semua nilai-nilai yang lain diabaikan kepada nilai yang satu ini.

\section{Gejala-gejala Kejiwaan}

Minderop (2011:38) gejala kejiwaan dapat diklasifikasikan dalam emosi sebagai berikut:

1. Konsep rasa bersalah. Rasa bersalah bisa disebabkan oleh adanya konflik antara ekspresi impuls dan standar moral (impuls expression versus moral standards). Rasa bersalah dapat pula disebabkan oleh prilaku neurotik,yakni ketika individu tidak mampu mengatasi problem hidup seraya menghindarinya melalui manuver-manuver defensif yang mengakibatkan rasa bersalah dan tidak bahagia.

2. Rasa bersalah yang dipendam. Dalam kasus rasa bersalah seseorang cenderung merasa bersalah dengan cara memendam dalam dirinya sendiri, memang ia merasa baik, tapi ia seorang yang buruk. 
3. Menghukum diri sendiri. Perasaan bersalah yang paling mengganggu adalah sebagaimana yang terdapat dalam sikap menghukum diri sendiri, si individu terlihat sebagai sumber dari sikap bersalah. Rasa bersalah tipe ini memiliki implikasi dengan berkembangnya gangguan-gangguan kepribadian yang terkait dengan kepribadian, penyakit mental dan psikoterapi.

4. Rasa malu, berbeda dengan rasa bersalah. Timbulnya rasa malu tanpa terkait dengan rasa bersalah. Perasaan ini tidak terdapat pada anak kecil.

5. Kesedihan atau dukacita (grief), berhubungan dengan kehilangan sesuatu yang penting atau bernilai, biasanya kesedihan yang teramat sangat bila kehilangan orang yang dicintai. Kesedihan yang mendalam bisa juga karena kehilangan milik yang sangat berharga dan mengakibatkan kekecewaan dan penyesalan. Parkes dalam Mindrop (2014:44) menemukan bukti bahwa kesedihan yang berlarutlarut dapat mengakibatkan depresi dan putus asa yag menjurus pada kecemasan, akibatnya bisa mengakibatkna imsomnia, tidak memiliki nafsu makan, timbul perasaan jengkel dan menjadi pemarah sehingga menarik diri dari pergaulan.

6. Kebencian atau perasaan benci (hate), berhubunga erat dengan perasaan marah, cemburu dan iri hati. Ciri khas yang menandai perasaan benci ialah timbulnya nafsu dan keinginan untuk menghancurkan objek yang menjadi sasaran kebencian. Perasaan benci bukan sekedar timbulnya perasan tidak suka atau aversi/enggan yang dampaknya ingin menghindar dan tidak bermaksud menghancurkan.

7. Perasaan marah (agresi), terkait dengan ketegangan dan kegelisahan yang dapat menjurus pada pengerusakan dan penyerangan. Agresi ini dapat berbentuk langsung dan pengalihan (direct aggression dan displaced aggression). Agresi langsung adalah agresi yang diungkapkan secara langsung kepada seeorang atau objek yang merupakan sumber frustasi. Bagi orang deasa, biasanya berbentuk verbal ketimbang fisikal, si korban yang tersinggung biasa akan merespon.

8. Cinta. Psikolog merasa perlu mnedefenisikan cinta dengan cara pemahaman mengapa timbulnya cinta 
dan apakah terdapat bentuk cinta yang berbeda-beda. Gairah cinta dari cinta romantis tergantung kepada si individu dan objek cinta, adanya nafsu dan keingian untuk bersama-sama. Mengenai cinta seorang anak kepada ibunya di dasari kebutuhan perlindungan, demikian juga cinta ibu kepada anaknya karena adanya keinginan melindungi.

\section{Pengertian Novel}

Sumardjo (1986:29) menyatakan bahwa, "Novel adalah cerita berbentuk prosa dalam ukuran luas". Ukuran yang luas disini dapat berarti cerita dengan plot (alur) yang komples, karakter yang banyak, tema yang kompleks, suasana cerita yang beragam, dan setting cerita yang beragam pula. Namun "ukuran luas" di sini juga tidak mutlak demikian, mungkin yang luas hanya salah satu unsur fiksinya saja, misalnya temanya, sedang karakter setting dan lain-lainnya hanya satu saja.

Istilah novel sama dengan istilah roman. Kata novel berasal dari Italia yang kemudian berkembang di Inggris dan Amerika Serikat. Novel dapat dibagi menjadi tiga golongan, yakni novel percintaan, novel petualangan, dan novel fantasi. Novel percintaan melibatkan peranan tokoh wanita dan pria secara seimbang, bahkan kadang-kadang peranan wanita lebih dominan. Novel petualangan sedikit sekali memasukkan peranan wanita. Jika wanita tersebut dalam novel jenis ini, maka penggambarannya hampir stereotip atau kurang berperan.

Novel fantasi adalah bercerita tentang hal-hal yang tidak realistis dan serba tidak mungkin dilihat dari pengalaman seharihari. Novel jenis ini menggunakan karakter yang tidak realistis, setting dan plot yang juga tidak wajar untuk menyampaikan ideide penulisannya.

\section{Biografi Pengarang}

Nama "Tere Liye" merupakan nama pena seorang penulis berbakat tanah air. Tere Liye sendiri di ambil dari bahasa India dan memiliki arti untukmu. Tere Liye lahir dan tumbuh dewasa di pedalaman Sumatera. Ia lahir pada tanggal 21 mei 1979. Tere Liye menikah dengan Ny.Riski Amelia dan di karunia seorang putra bernama Abdullah Pasai. Seperti di sebutkan di atas, Tere Liye tumbuh di Sumatera Pedalaman. Ia berasal dari keluarga sederhana yang orang tuanya berprofesi sebagai petani biasa. Anak ke enam dari tujuh bersaudara ini sampai saat ini telah menghasilkan 14 karya. Bahkan beberapa di antaranya telah di angkat ke layar lebar. 
Berdasarkan email yang di jadikan sarana komunikasi dengan para penggemarnya yaitu darwisdarwis@yahoo.com. Bisa di simpulkan sederhana bahwa namanya adalah Darwis. Tere Liye menyelesaikan masa pendidikan dasar sampai SMP di SDN2 dan SMAN 2 Kikim Timur, Sumatera Selatan. Kemudian melanjutkan ke SMUN 9 Bandar Lampung. Setelah selesai di Bandar Lampung, ia meneruskan ke Universitas Indonesia dengan mengambil fakultas Ekonomi.

Tere Liye salah satu penulis yang telah banyak menelurkan karya-karya terbaik. Selain memiliki tingkat kesusastraan tinggi, ia merupakan sastrawan yang misterius. Berbeda dengan penulis-penulis lain, Tere Liye memang sepertinya tidak ingin dipublikasikan ke umum terkait kehidupan pribadinya. Mungkin cara yang ia pilih untuk mendekatkan diri dengan pembaca setia karya-karyanya adalah dengan cara memberikan karya terbaiknya. Dari karya-karyanya Tere Liye ingin membagi pemahaman bahwa sebetulnya hidup ini tidaklah rumit seperti yang sering terpikir oleh kebanyakan orang. Hidup adalah anugrah sang Kuasa dan karena anugrah berarti harus disyukuri.

\section{Sinopsis Novel "Daun yang Jatuh Tak Pernah Membenci Angin" karya Tere Liye}

Tania adalah anak yang cerdas, tangguh dan berparas cantik. Tania tinggal bersama adik dan ibunya. Karena keterbatasan ekonomi ia harus putus sekolah dan menjadi pengamen di jalanan. Kehidupan mereka berubah setelah bertemu dengan seorang pria bernama Danar. Danar adalah seorang karyawan yang juga penulis buku anak-anak. Danar begitu baik sehingga keluarga ini menganggapnya seperti malaikat. Tania sangat mengagumi Danar karena selain baik, dia juga punya wajah yang menawan.

Kebahagiaan mereka berkurang saat ibu Tania meninggal. Sekarang ia yang harus bertanggung jawab menjaga adiknya. Tania tumbuh menjadi gadis yang cantik dan pintar. Perasaannya terhadap Danar juga semakin jelas. Lambat laun Tania tahu, perasaan itu bernama cinta. Ia berhasil mendapatkan beasiswa ke Singapura. Ketika Tania dan Danar sama-sama tahu perasaan mereka masing-masing, semua sudah terlambat. Biar bagaimanapun Danar telah menikah dengan Ratna. Akhirnya Tania kembali ke Singapura dan memutuskan untuk meninggalkan semua cerita cintanya. 
HASIL DAN PEMBAHASAN

Gejala Kejiwaan tokoh-tokoh dalam novel Daun yang Jatuh Tak Pernah Membenci Angin karya Tere Liye

\begin{tabular}{|c|c|c|c|}
\hline $\mathbf{N}$ & $\begin{array}{c}\text { Nam } \\
\text { a }\end{array}$ & $\begin{array}{c}\text { Gejala } \\
\text { Kejiwaan }\end{array}$ & $\begin{array}{c}\text { Halama } \\
\text { n }\end{array}$ \\
\hline 1. & Tania & $\begin{array}{l}\text { 1. Konsep } \\
\text { rasa } \\
\text { bersalah } \\
\text { 2. Rasa } \\
\text { bersalah } \\
\text { yang } \\
\text { dipendam } \\
\text { 3. Menghuk } \\
\text { um diri } \\
\text { sendiri } \\
\text { 4. Rasa } \\
\text { malu } \\
\text { 5. Kesediha } \\
\text { n atau } \\
\text { duka cita } \\
\text { 6. Kebencia } \\
\mathrm{n} \text { atau } \\
\text { perasaan } \\
\text { benci } \\
\text { Perasaan } \\
\text { marah } \\
\text { Cinta }\end{array}$ & $\begin{array}{l}81,123 \\
152, \\
159,191 \\
125,162 \\
14, \quad 81, \\
129 \\
11, \quad 61, \\
76 \\
39,118, \\
127 \\
61,102, \\
120, \\
123,127 \\
94,154, \\
161,164\end{array}$ \\
\hline 2. & $\begin{array}{l}\text { Dana } \\
\mathrm{r}\end{array}$ & $\begin{array}{l}\text { 1. Rasa } \\
\text { bersalah }\end{array}$ & 164 \\
\hline
\end{tabular}

\begin{tabular}{|l|l|l|l|}
\hline & yang & 149 \\
dipendam & 142 \\
2. & Menghuk & 56 \\
um diri & 242, \\
sendiri & 248,240 \\
3. & Kesediha \\
& n atau & \\
& duka cita & \\
4. & Perasaan \\
marah & \\
5. Cinta & \\
\hline
\end{tabular}

\section{a. Tania}

Gadis jelita itu bernama Tania. Tubuhnya yang tinggi, memiliki kulit putih bersih serta rambut panjang yang lebat terurai, membuatnya menjadi salah satu gadis tercantik. Dengan kecantikan paras dan raganya itu, tak sedikit teman-teman lelaki sebayanya memiliki perasaan kepadanya. Namun, di samping kesempurnaan paras yang ia miliki, kehidupan Tania jauh dari kata sempurna, ia hidup di rumah kardus bersama Ibu dan Adik laki-lakinya. Meski begitu tak sedikitpun mengurangi kebahagiaannya, Tania adalah tokoh utama atau protagonis di dalam novel Daun yang Jatuh Tak Pernah Membenci Angin karya Tere Liye. Tania digambarkan sebagai tokoh gadis yang cerdas, tangguh, pekerja keras 
dan memiliki prinsip hidup yang kuat. Kemampuannya dalam bidang akademik tidak perlu diragukan, ia berhasil lulus dalam tes seleksi ASEAN Scholarship dan diterima menjadi siswa SMP di salah satu sekolah terkenal di Singapura. Tiga tahun lewat bagai kejap mata, Tania lulus nomor satu untuk dua puluh dua penerima ASEAN Scholarship seluruh negara. Kemudian, di senior high school-nya Tania berhasil menjadi juara satu. Di bangku kuliahnya, Tania hanya butuh dua tahun setengah untuk menyelesaikan bachlor degree-nya di jurusan Commerce NUS. GPA (grade point average)-nya. Tania lulusan terbaik dalam sejarah kampus tersebut. Nama Tania dipahat di plakat depan halaman kampusnya. Sekarang Tania sudah bekerja di salah satu perusahaan pialang Singapura. Perusahaan spekulan terbesar di Asia Pasifik.

Semua kesuksesan Tania di bidang pendidikan dan karirnya, sayangnya berbanding terbalik dengan kisah cintanya. Sejak rambutnya masih di kepang dua, umurnya masih dua belas tahun, dan ia belum beranjak dewasa, Tania hanya mencintai satu lelaki yaitu Danar. Danar yang seorang penulis itu, telah memiliki seorang kekasih bernama Ratna.

\section{Konsep rasa bersalah}

Konsep rasa bersalah Tania muncul ketika ia bertanya tentang hubungan Danar dan Ratna. Hal tersebut dapat dilihat dari kutipan berikut:

Aku entah harus tertawa atau sedih. Ah, seharusnya aku bisa bertanya dulu ke adikku. Dede tentu tau semua hal tentangnya. Pertanyaan langsung seperti ini mungkin mengganggunya, tetapi sudahlah, aku sudah terlanjur bertanya.

(Hal.81)

Aku lupa bahwa dulu kak Ratna ikut menemani di rumah. Membawakan selimut dan baju ganti. Membimbingku saat pulang dari pemakaman Ibu. Menemaniku di rumah kontrakan, dan lain sebagainya. Otakku sedang benci, maka aku harus berpikiran negatif sepanjang hari.

(Hal. 123)

2. Rasa bersalah yang dipendam

Rasa bersalah yang dipendam oleh Tania ketika ia tidak pulang di hari pernikahan Danar dan Ratna. Hal tersebut dapat dilihat dari kutipan-kutipan berikut:

Bukankah aku bukan siapa-siapa dia? $\mathrm{Aku}$ hanyalah anak kecil yang dipungut dari jalanan. Diberi kehidupan yang 
indah, dijanjikan masa depan yang baik. Dan sekarang, lihatlah balasan apa yang aku berikan? Merajuk tak mau pulang tanpa alasan yang jelas.

(Hal.152)

Sayang ia tidak datang ketika aku diwisuda. Bagaimana dia akan datang jika ternyata semenjak kejadian itu dia tak pernah menghubungiku secara langsung? Semenjak pernikahan itu.

(Hal.159)

Mataku berdenting air. Berkaca-kaca. Aku tak seharusnya memiliki jarak ini. Aku tak sepantasnya membuat ketidaknyamanan ini. Anne benar, seharusnya akulah yng lebih dulu mengirimkan e-mail dan chatting. Akulah yang mesti memulainya. Karena semua masalahnya ada dihatiku.

(Hal.191)

\section{Menghukum diri sendiri}

Tania menghukum dirinya sendiri setelah pernikahan Danar dan Ratna. Hal tersebut dapat dilihat dari kutipan berikut ini:

Tidak. Aku tidak akan menangis, Ibu. Walaupun dulu sebelum kau pergi kau mengizinkan aku untuk menangis demi dia.

(Hal.125)
Sehari setelah pernikahan, saat mereka berangkat bulan madu. Aku memutuskan untuk melakukan banyak hal sepanjang sisa tahun. Sepanjang kehidupan di Singapura. Hidupku harus penuh dengan kesibukan. Kesibukan-kesibukan yang akan membuatku lelah berpikir. Pelanpelan semuanya akan berlalu. Kalau aku sedikit beruntung, mungkin bisa melupakannya.

(Hal.162)

\section{Rasa malu}

Di balik sikap Tania yang tegas dan berpendiran, ia juga seorang gadis yang mempunyai rasa malu ketika Andi temannya mengatakan perasaannya di depan umum dan Danar memujinya . Hal tersebut dapat dilihat dari kutipan berikut:

Aku menggeleng, bukan tidak percaya ucapan anehnya. Tetapi memohon. Tolong hentikan kekonyolan ini, aku mendesah dalam hati sambil menyibak rambut panjangku yang basah menutupi mata.

(Hal. 14)

Terlihat sekali dia membanggakanku di depan tetangga. Dan aku sering tersipu malu. Tak banyak berkata, meskipun sungguh aku senang dipuji olehnya. Aku menatap siluet wajah menyenangkan itu yang ditimpa api unggun yang 
dihidupkan Dede. Semenjak detik itu, aku memperbaharui banyak hal dalam hati.

(Hal. 81)

Aku hanya menunduk. Aku tidak bisa menjelaskan seperti apa perasaan dihatiku sekarang. Tidak terkatakan. Semua ini sungguh membanggakan.

(Hal.129)

\section{Kesedihan atau duka cita}

Tania merasakan kesedihan yang mendalam ketika Ibunya meninggal dunia. Hal tersebut dapat dilihat dari kutipankutipan berikut:

Menatap pengunjung lain yang sibuk, sedikit banyak membantuku berdamai dengan perasaan masa lalu. Tempat ini benar-benar berarti banyak bagiku. Menyimpan kepentingan penting.

(Hal. 11)

Aku hanya duduk termangu. Tidak mampu bersuara sedikitpun di sudut ruangan kontrakan. Mengenakan kerudung hitam yang diberikan kak Ratna. Adikku duduk bingung menatap tubuh Ibu yang terbungkus ketat kain kafan. Semua mata memandang bersedih ke arahku dan Dede.

(Hal.61)

Satu tahun pertama aku belum bisa dengan sempurna melupakan kenangan atas kematian Ibu yang menyedihkan.
Pembicaraan kami sekali-dua membahas tentang kenangan lama itu (dia pandai mengalihkan pembicaraan).

(Hal.76)

6. Kebencian atau perasaan benci

Seketika hati kecilku tidak terima. Sakit hati! Kalau kami pergi entah ke mana, akulah yang lengannya digenggam? Akulah yang pundaknya dipegang? Akulah yang kepalanya diusap. Itu jelasjelas posisiku!

Aku benci sekali.

Tetapi kenapa ia harus datang bersama kak Ratna. Kenapa? Pidato yang kusiapkan jadi kacau balau.

(Hal. 127)

"Tania..., hanya itu kata yang keluar dari mulutnya. Terkejut. Tersenyum ringan. Berdiri, melangkah, mendekat, memelukku.

Dan aku seketika amat benci dengan pelukannya.

"Wah....surprice!" kak Ratna ikut-ikutan berdiri.

Ikut-ikutan memelukku. Aku jauh lebih benci. 


\section{Perasaan marah}

Tania marasakan perasaan marah. Hal ini terlihat dari kutipan-kutipan berikut ini:

Aku tidak percaya angka tiga belas membawa sial, takdir, sore itu Ibuku meninggal. Pergi selama-lamanya dari kami.

Ibu tak pernah bangun lagi dari pingsannya. Menggigit bibir keras-keras agar air mataku tidak tumpuh.

"Paling dari pacar baru Oom Danar," Dede santai sekali mengatakan itu sambil mengunyah daging sapinya.

Aku mendadak kehilangan selera makan.

(Hal. 102)

Posisiku sempurna diambil alih Kak Ratna. Dan itu jauh lebih menyakitkan dibandingkan saat di Dunia Fantasi dulu (akukan belum tahu apa namanya perasaan saat itu)

(Hal. 120)

Karena kemana-mana kami pergi kak Ratna selalu ikut. Aku protes dalam hati karena kak Ratna ternyata juga ikut kepemakaman Ibu. Kak Ratna sama sekali tak ada hubungannya dengan Ibu, kan? Siapa dia? Kenapa pula ikut?

(Hal.123)
Ya tuhan! Tidak, lihatlah, di belakangnya ternyata ada Kak Ratna yang mengiringi. Ikut bertepuk tangan bersama wisudawan dan undangan lainnya. Semua bayangan hebat dalam film-film itu langsung runtuh seketika tak bersisa.

(Hal.127)

\section{Cinta}

Tania mencintai Danar, benar-benar mencintainya. Hal tersebut dapat dilihat dari kutipan-kutipan berikut:

Aku tentu saja tetap menyerahkan kue itu kepadanya. Dia menerimanya sambil tersenyum. Mendekap bahuku. Mencium rambutku. Anne menyenggol lenganku, menatap penuh arti. Jhony Chan menatap sebal di depan meja.

(Hal. 94)

Aku mencintainya. Itulah semua perasaanku.

Berdosakah aku mencintai malaikat kami? Salahkah kalau di antara perhatian dan sayangnya selama ini kepada Ibu, adikku dan aku sendiri, perasaan itu muncul mekar? Aku sama sekali tidak impulsif. Perasaan itu muncul dengan alasan yang kuat. Dari seorang kanakkanak yang rambutnya masih dikepang dua. Dari seorang gadis yang belum beranjak dewasa.

(Hal.154) 
Tidak. Aku dulu sedikit pun tidak malu memiliki perasaan ke seseorang yang jauh sekali dari jangkauanku. Kanak-kanak yang tak memiliki apaapa. Jatuh cinta kepada seorang malaikat. Ah, aku tak peduli.

(Hal.161)

Satu: Dia tahu aku mencintainya, tetapi ia sama sekali tak mencintaiku. Dia selama ini menyayangiku. Namun itu merupakan sayang seorang kakak kepada adiknya.

Dari kutipan-kutipan di atas dapat diketahui bahwa tokoh Tania dalam novel Daun yang Jatuh Tak Pernah Membenci Angin karya Tere Liye memiliki gejalagejala kejiwaan yaitu Tania merasakan konsep rasa bersalah ketika Tania menanyakan hubungan Danar dan Ratna kepada Dede dan pada saat Tania membenci Ratna karena rasa cemburunya, Rasa bersalah yang dipendam ketika Tania benarbenar mencintai Danar kakaknya, Tania menghukum diri sendiri saat Tania berjanji kepada Ibunya untuk tidak menangis, Tania menghukum dirinya sendiri saat ia tidak pulang dihari pernikahan Danar padahal ia sangat merindukan adiknya Dede dan suasana rumah, di balik sikapnya yang mandiri dan tangguh Tania juga seorang yang pemalu hal ini terlihat ketika Andi temannya mengatakan perasaannya kepada Tania di depan umum, ketika Danar memujinya. Tania merasakan kesedihan atau duka cita ketika Ibunya meninggal dan Danar menikahi Ratna, Tania juga merasakan perasaan benci, ia membenci Ratna karena Ratna telah mengambil alih posisinya di rumah dan di hati Danar, ketika Ratna datang di hari wisudanya, selain itu gejala lain muncul Tania merasa marah dengan angka tiga belas karena pada saat itu Ibunya meninggal dan Tania membenci Ratna atas kehadiran Ratna diantara Tania dan Danar dan yang terakhir Tania merasakan cinta yang besar terhadap Danar karena perhatian dan kasih sayang Danar kepadanya.

\section{b. Danar}

Danar adalah seorang karyawan swasta dan penulis buku, ia memiliki hati yang sangat baik. Danar memiliki raut mukanya yang menyenangkan. Tawanya yang tulus kebaikannnya pada anak-anak, dan kecintaannya untuk berbagi. Tak satupun pengalaman buruk yang ia rasakan semasa kecilnya meninggalkan kepedihan.

Danar anak yang yatim piatu sejak bayi (siapa orang tuanya pun tidak ada yang tahu). Berjuang di jalanan untuk 
mempertahankan hidup seperti yang dilakukan oleh Tania dan adiknya dulu. Mungkin lebih menyakitkan karena tak ada yang berbaik hati membantunya. Karena kesamaan pengalaman hidup yang membuat Danar sayang kepada Tania dan Dede. Danar memberikan mereka harapan hidup, tempat tinggal dan menyekolahkan mereka. Sampai akhirnya Ibu Tania meninggal dunia.

Danar merasakan rasa bersalah yang dipendam. Hal tersebut dapat dilihat dari kutipan berikut:

Ketika aku menolak pulang saat pernikahan mereka, dia telah merasa berbuat jahat kepadaku. Dia tak mampu menjelaskan kepadaku tentang bagaimana seharusnya aku mengubah perasaan cinta itu. Dia mungkin juga merasa bersalah dengan membiarkan perasaan itu muncul di hatiku. Dia tidak ingin membuat masalahnya semakin rumit, maka ia menghindariku.

Karena Tania tidak akan pulang saat pernikahannya, Danar menghukum dirinya sendiri. Hal tersebut dapat dilihat dari kutipan berikut:

"Kalau kau tidak bisa pulang, bisakah kau membujuknya untuk kembali bersemangat? Tolong kakakmu Tania. Bantu aku untuk menyakinkan bahwa keputusan kami untuk menikah ini benar.

(Hal.149)

Danar merasakan kesedihan ketika ia berkali-kali membujuk Tania untuk pulang di hari pernikahannya dengan Ratna, namun Tania menolak untuk pulang. Hal tersebut dapat dilihat dari kutipan berikut:

Di seberang telepon, dia terdengar menarik nafas dalam-dalam. Amat panjang. Aku mengeluh mendengarnya. Tentu saja aku telah membuatnya kecewa. Ya Tuhan, bukankah aku pernah bersumpah untuk selalu menuruti katakatanya.

(Hal. 142)

Danar marah kepada dokter karena tak mampu menyelamatkan Ibu Tania. Hal tersebut dapat dilihat dari kutipan berikut:

"Bagaimana mungkin? Kalian harus melakukan apa saja agar dia bisa sembuh!" Dia menekan suaranya sedemikian rupa agar tidak terdengar kami. 
“ Kau lihat." Dia menarik tangan dokter itu kasar keluar ruangan. Menunjuk kami yang tertidur di balik selimut.

"Kau lihat siapa yang akan kehilangan kalau dia meninggal. Anak-anak itu tak punya siapa-siapa lagi selain dia. Ya Tuhan, lakukanlah apa saja aku mohon..."suaranya parau.

(Hal.56)

Danar cinta kepada Tania, cinta yang sudah bertahun-tahun disimpannya rapatrapat. Hal tersebut dapat dilihat dari kutipan berikut:

"Bukankah gadis kecil dalam novel yang tak pernah selesai itu aku?" Aku mendesis menatapnya terluka.

“Apa maksudmu?” Suaranya bergetar.

"Aku tak tahu kau juga memiliki perasaan itu....aku pikir dengan menikahi Kak Ratna semua jelas seperti bintang gemintang.

(Hal. 248)

Tetapi kau tak pernah mengakui telah jatuh cinta pada gadis berumur dua belas tahun.

Tak masuk akal kan? Kau yang sedewasa dan sehebat itu jatuh cinta pada gadis kecil yang rambutnya masih dikepang dua berpita merah.

Berdasarkan kutipan-kutipan di atas dapat dikatakan bahwa tokoh Danar dalam novel Daun yang Jatuh Tak Pernah Membenci Angin karya Tere Liye memiliki gejala-gelaja kejiwaan yaitu Danar merasakan rasa bersalah yang dipendam karena tidak dapat menyelamatkan nyawa Ibu Tania, Danar menghukum diri sendiri karena ketidakpulangan Tania, Danar merasakan kesedihan ketika Tania tidak pulang saat hari pernikahannya, dan yang terakhir Danar merasakan cinta kepada Tania, cinta yang dipendam selama bertahun-tahun.

\section{SIMPULAN}

Setelah peneliti menganalisis novel Daun yang Jatuh Tak Pernah Membenci Angin karya Tere Liye dengan pendekatan psikologis yang kemudian membaca dan menginterpretasikan perwatakan dengan tokoh-tokoh dalam novel tersebut, maka peneliti menarik simpulan sebagai berikut:

1. Tokoh Tania dalam novel Daun yang Jatuh Tak Pernah Membenci Angin karya 
Tere Liye adalah seorang gadis cerdas, tangguh, dan pekerja keras, ia memiliki gejala-gejala kejiwaan yaitu Konsep rasa bersalah Tania muncul ketika Tania membenci Ratna tanpa alasan karena perasaan cemburunya yang tidak beralasan, dan saat ia bertanya tentang hubungan Danar dan ratna, Rasa bersalah yang dipendam dalam diri Tania muncul ketika ia mencintai Danar. Tania menghukum dirinya sendiri untuk tidak menangis untuk hal apapun kecuali tentang Danar dan Tania menghukum dirinya sendiri untuk tidak pulang ke Indonesia, Tania merasa malu Tania merasa malu karena Andi temannya mengungkapkan perasaan cintanya kepada Tania di depan umum dan Tania malu karena dipuji oleh Danar dan atas perasaannya, Tania merasakan kesedihan atau duka cita yang mendalam ketika ia mengenang Danar di toko buku, ibunya meninggal dan Danar menikah dengan Ratna, Tania juga merasa benci kepada Ratna karena perhatian Danar tak lagi untuknya, Tania melihat Danar dan Ratna bercengkrama, dan saat Ratna datang pada hari wisuda Tania padahal kehadirannya tidak diinginkan oleh Tania, Tania merasa marah kepada Dede karena Dede mengatakan Danar telah memiliki kekasih baru dan Tania marah saat posisinya diambil alih oleh Ratna dengan angka tiga belas dan atas kehadiran Ratna diantara Tania dan Danar, dan yang terakhir Tania merasakan cinta yang besar terhadap Danar.

2. Tokoh Danar dalam novel Daun yang Jatuh Tak Pernah Membenci Angin karya Tere Liye adalah berhati baik, penolong, dan pekerja keras, ia memiliki gejalagelaja kejiwaan yaitu Danar merasakan perasaan marah, merasa bersalah yang mendalam karena tidak dapat menyelamatkan nyawa Ibu Tania, Danar merasakan kesedihan ketika Tania tidak pulang saat hari pernikahannya, Danar menghukum diri sendiri karena ketidakpulangan Tania dan yang terakhir Danar merasakan cinta kepada Tania, cinta yang dipendam selama bertahuntahun.

\section{B. Saran}

Sehubungan dengan hasil temuan penelitian di atas, maka yang menjadi saran peneliti adalah sebagai berikut:

1. Dengan bantuan psikologis, dapat membantu peneliti melihat dan mengamati gambaran watak tokoh-tokoh tersebut sesuai dengan apa yang kita ketahui tentang jiwa manusia. 
2. Bagi peneliti lain hendaknya disarankan agar menjadikan penelitian ini sebagai sumber informasi dan bahan masukan sehingga bermanfaat dalam mengkaji nilai-nilai lain sewaktu melaksanakan penelitian dalam bidang yang relevan.

\section{DAFTAR PUSTAKA}

Aminuddin. 2002. Pengantar Apresiasi Karya Sastra. Malang: FPBS IKIP Malang.

Arikunto, Suharsimi. 2007. Prosedur Penelitian Suatu Pendekatan Praktik. Jakarta: Rineka Cipta.

Chaer, Abdul. 2009. Psikolinguistik Kajian Teoretik. Jakarta: Rineka Cipta.

Endraswara, Suwardi. 2002. Metode Penelitian Psikologi Sastra. Yogyakarta: Media Pressindo.

Emzir, dan Saiful Rohman. 2015. Teori dan Pengajaran sastra. Jakarta: PT. Raja Grafindo Persada.

Kutha, Nyoman. 2015. Teori, Metode, dan Teknik Penelitian Sastra. Yogyakarta: Pustaka Pelajar.

Liye, Tere. 2010. Daun Yang Jatuh Tak Pernah Membenci Angin. Jakarta:PT. Gramedia Pustaka Utama.

Minderop, Albertine. 2011. Psikologi Sastra, Karya Sastra, Metode, Teori, dan Contoh Kasus. Jakarta. Yayasan Pustaka Obor Indonesia.

Nurgiantoro, Burhan. 1995. Teori Pengkajian Fiksi. Yogyakarta: Gaja Mada Press.
Rokhmansyah, Alfian. 2014. Studi dan Pengkajian Sastra. Yogyakarta: Grahu Ilmu.

Suryabrata, Sumadi. 2011. Psikologi Kepribadian. Jakarta. Rajawali Pers.

Syah, Muhibin. 2001. Psikologi Pendidikan dengan Pendekatan Baru. Bandung: Remaja Rosdakarya.

Sumardjo, Jakob dan Saini K.M. 1986. Apresiasi Kesusastraan. Jakarta: Gramedia. 